\title{
MENINGKATKAN DAYA SAING PRODUK USAHA MIKRO MELALUI DESAIN KEMASAN KELOMPOK USAHA PRODUSEN DAN RETAILER MAKANAN "KUE SUBUH"
}

\section{IMPROVING COMPETITIVENESS OF MICRO BUSINESS PRODUCTS THROUGH FOOD CAKE PACKAGING AND FOOD BUSINESS BUSINESS PACKAGING DESIGN}

\author{
Nurprapti Wahyu Widyastuti ${ }^{1}$, Rahmi Winangsih ${ }^{2}$ \\ ${ }^{12}$ Prodi Ilmu Komunikasi Universitas Sultan Ageng Tirtayasa \\ Email: ${ }^{1}$ nurprapti.wahyu@ untirta.ac.id, rahmi.winangsih@untirta.ac.id
}

\begin{abstract}
ABSTRAK
Produk makanan yang dikenal sebagai jajanan pasar banyak dijajakan di pasar tradisional. Industri produk tersebut di atas masih berskala mikro, dan bersifat rumahan. Pemasok produk kue di pasar subuh berasal dari berbagai lokasi di Jakarta, Tangerang, Serang Kota dan sekitarnya. Sistem pemasaran produk meliputi 3 cara yaitu: (1) menjual produk ke pasar kue subuh, (2) menjual ke toko, dan (3) menerima pesanan dari kantor/pribadi. Mereka memproduksi dalam skala besar untuk dijual di pasar subuh, sisa produk tidak habis dijual di toko kue. Retailer adalah para pengecer pembeli produk kue subuh untuk dijual kembali ke segmentasi dan target pasar berbeda. Para retailer memesan kue untuk dipasarkan pada perkantoran, komunitas tertentu seperti arisan, pesta perkawinan/ulang tahun, maupun acara-acara lainnya, bahkan ada yang telah menjalin kerjasama dengan industri penerbangan untuk melayani kebutuhan catering. Berdasarkan studi awal yang penulis lakukan, ada korelasi positif antara bentuk dan kualitas kemasan produk dengan minat konsumen untuk membeli produk. Sementara itu, dari hasil wawancara awal dengan pelaku usaha mikro produk makanan, baik produsen maupun retailer mengakui bahwa kemasan produk mempengaruhi citra produk. Namun pemahaman mereka tentang kemasan produk masih sangat minim. Menurut mereka kemasan hanya sekedar wadah dan pembungkus makanan agar tidak rusak. Permasalahan lain yaitu mereka tidak mempunyai kemampuan dana untuk mengemas produknya dengan baik. Dengan situasi persaingan semakin tajam, desain sebuah kemasan merupakan suatu nilai tambah, dapat berfungsi sebagai media promosi dan untuk menjaring konsumen.
\end{abstract}

Kata Kunci: Daya saing UKM, Kemasan produk UKM, Kue Subuh

\begin{abstract}
Food products known as market snacks are sold in traditional markets. The product industry above is still micro-scale, and is home-based. Cake product suppliers in the dawn market come from various locations in Jakarta, Tangerang, Serang City and surrounding areas. The product marketing system includes 3 ways: (1) selling products to the dawn cake market, (2) selling to the store, and (3) receiving orders from the office / personal. They produce on a large scale for sale in the dawn market, the rest of the product is not sold out at the cake shop. Retailers are retailers who buy dawn cake products to sell back to different segments and target markets. The retailers order cakes to be marketed in offices, certain communities such as arisan, wedding / birthday parties, and other events, and some have collaborated with the aviation industry to serve catering needs. Based on the initial study that the authors did, there was a positive correlation between the shape and quality of product packaging and consumers' interest in buying
\end{abstract}


products. Meanwhile, from the results of preliminary interviews with food product micro entrepreneurs, both producers and retailers acknowledge that product packaging affects product image. But their understanding of product packaging is still very minimal. According to them, the packaging is only a container and food packaging to avoid damage. Another problem is that they do not have the ability to fund their products properly. With the competition situation getting sharper, the design of a packaging is an added value, can function as a media campaign and to capture consumers.

Keywords: SME competitiveness, SME product packaging, Kue Subuh

\section{PENDAHULUAN}

Pada saat ini tantangan dan hambatan yang dihadapi dalam dunia usaha semakin besar. Salah satunya kegiatan yang pesat perkembangannya adalah kegiatan jual-beli (dagang) khususnya dalam bidang usaha makanan. Persaingan terjadi semakin ketat hal ini ditandai dengan banyaknya usaha dagang yang menerapkan berbagai strategi untuk mempertahankan kelangsungan usahanya. Usaha kue basah dan kue kering ini adalah usaha yang paling mudah untuk dikembangkan. Karena banyaknya peminat kue-kue basah dan kering ini. Kue ini juga termasuk jenis makanan yang mudah diterima diberbagai kalangan masyarakat. Bukan hanya itu bahan-bahan untuk membuat kue basah dan kue kering ini pun sangat mudah untuk diperoleh. Proses pembuatan kue-kue basah dan kering ini sangat mudah. Modal yang dibutuhkan tidak begitu banyak namun mampu memberikan keuntungan besar. Selain memperoleh keuntungan besar, usaha ini juga mempunyai beberapa resiko merugikan pemiliknya.

Produk kue basah dan kue kering yang dipasarkan di pasar subuh nyaris tidak dikemas sama sekali. Kue yang sudah jadi dan siap dipasarkan ditaruh dalam loyangloyang besar, kardus dan keranjang plastic. Kue ini jual secara eceran per lusin atau per sepuluh buah, maupun per satuan. Untuk jenis kue-kue tertentu, biasanya kue yang berukuran kecil/kue unyil/kue mini, dijual per kotak isi 30/40/50 buah. Baik kue yang dijual per satuan maupun perkotak tidak dikemas dengan baik dan terkesan seadanya. Kotak kue terbuat dari kardus polos dengan material kardus yang kurang bagus.

Mitra kegiatan pengabdian masyarakat ini ada 2 dua, yaitu: pertama adalah kelompok produsen makanan kue subuh, dan yang kedua adalah kelompok retailer makanan kue subuh. Kedua kelompok mitra program pengabdian pada masyarakat ini adalah kelompok usaha mikro yang tumbuh, berkembang sejalan dengan dinamika masyarakat perkotaan. Tingginya bahan baku untuk membuat kue dan gaya hidup masyarakat perkotaan yang menginginkan serba dinamis membuat industi ini mendapat 
ruang untuk berkembang. Masyarakat lebih suka membeli kue jadi karena harganya lebih ekonomis, praktis, dan mudah didapat.

Berdasarkan pengamatan, hasil diskusi dan observasi di lapangan, kualitas produk kue-kue produk usaha mikro calon mitra program dapat dikategorikan bagus baik bentuk dan cita rasanya. Kesulitan yang timbul adalah ketika mereka mendapat order dari retailer yang menghendaki produk dikemas dengan baik. Para retailer akan menjual kembali kue-kue tersebut ke took-toko roti dan kue, catering, maupun memenuhi pesanan konsumen perkantoran. Kemampuan mengemas produk menjadi sesuatu yang lebih menarik tentu saja akan berkorelasi positif dengan citra produk dan harga jualnya. Cita rasa, bentuk dan kemasan akan mempengaruhi harga jual produk. Atas dua fenomena tersebut di atas, maka baik produsen maupun retailer "kue subuh" dituntut mempunyai kemampuan merancang dan membuat kemasan produk dengan baik. Beberapa permasalahan yang mendasar dihadapi pengusaha mikro antara lain adalah sebagai berikut :

1. Mereka hanya fokus pada produksi kue dan memasarkannya tanpa mencoba memberikan nilai tambah pada kemasan produk.

2. Mereka tidak menyadari arti penting kemasan dalam meningkatkan citra produk dan nilai jualnya

3. Mereka tidak mengetahui fungsi kemasan baik terhadap produk maupun aspek komunikasi pemasarannya.

4. Mereka tidak mempunyai pengetahuan yang memadai mengenai desain kemasan produk

5. Mereka tidak mempunyai keterampilan membuat kemasan produk yang mempunyai fungsi melindungi produk dan estetika kemasan-produk.

Untuk dapat memenangkan persaingan, seorang pengusaha harus mempunyai daya pikir kreatif dan inovatif. Mereka harus mampu melakukan beberapa terobosan dalam meningkatkan nilai jual produk. Up-grading pengetahuan dan keterampilan dilakukan untuk meningkatkan kreatifitas dan inovasi hasil produksi, adalah menjadi kewajiban pemerintah dan perguruan tinggi sebagai masyarakat ilmiah untuk melakukan pembinaan terhadap para pengusaha mikro, sehingga mereka dapat bertahan dan bahkan tumbuh berkembang menjadi lebih maju dan lebih luas lingkup usahannya. Terlebih mereka 
harus mampu bersaing dengan produk impor maupun bersaing dengan pengusaha berskala besar.

Mitra kegiatan program $\mathrm{I}_{b} \mathrm{M}$ Kelompok Usaha Produsen dan Retailer Makanan "Kue Subuh" adalah para pelaku usaha kecil menengah yang bergabung dalam Koperasi forum umkm "mandiri” Banten. Anggota koperasi UMKM mandiri berjumlah 52 orang. Mereka adalah para pemilik usaha kecil dan menengah yang memproduksi makanan baik berupa kue basah maupun kue kering serta bentuk makanan khas banten lainnya.

Tentang koperasi forum UMKM "Mandiri" Banten, Lebih jauh digambarkan sebagai berikut: Koperasi forum UMKM "Mandiri" Banten berbadan hukum no : 51/BH/518-Bid-Ko/X/2010, yang didirikan pada Tanggal 20 oktober 2010. Koprasi ini didirikan atas dasar keinginan untuk mempererat tali silaturahmi sebagai wadah UMKM yang berdomisili di kota Serang yaitu forum koperasi UMKM kota Serang, berkumpul dan berkomunikasi dalam senasib maka terbentuklah koperasi pada tahun 2010. Pada, awal pendiriannya koperasi lebih sebagai wadah dalam mencari solusi klasik anggota yang selalu membutuhkan dorongan modal demi kelancaran usahanya. Untuk selanjutnya pemasaran adalah solusi kedua bagi anggota pelaku UMKM di komunitas ini.

Kedudukan koprasi ini adalah di kota serang, dengan alamat Sekretariat di Jl Yumaga No. 23P Benggala Pesantren Serang, Telepon : 0254282989, Fax: 02548485062. Untuk surat menyurat dan kepentingan administrasi lainnya dapat menggunakan media internet, bisa dialamatkan kepada alamat e-mail kpfor_umkmserang@yahoo.com, dan bagi yang ingin mendapatkan informasi lebih jauh mengenai koperasi ini dapat dilihat di web site www.koperasi-umkmserang.co.id. Mitra kegiatan $\mathrm{I}_{\mathrm{b}} \mathrm{M}$ Kelompok Usaha Produsen dan Retailer Makanan "Kue Subuh" adalah para pelaku usaha UMKM yang bergabung dalam koperasi. Keanggotaan Koperasi Forum UMKM "Mandiri" Banten adalah perorangan yang melakukan kegiatan usaha di Wilayah Provinsi Banten. Anggota koprasi sampai saat ini sudah mencapai 52 orang pengusaha IKM dan UMKM yang tersebar di 6 (enam) Kecamatan di Kota Serang, Kabupaten Pandeglang, Kota Cilegon dan Kabupaten Serang. 


\section{METODE PELAKSANAAN}

\section{Penyuluhan/Penyadaran}

Pemahaman mengenai fungsi, bentuk, manfaat material dan estektika kemasan seperti yang telah diuraikan dalam tersebut di atas dapat ditularkan pada khalayak sasaran melalui 2 tahapan kegiatan yaitu (1) kegiatan workshop dan (2) pendampingan dalam perancangan sampai dengan implementasi pembuatan kemasan produk. Kegiatan workshop yaitu pemberian wawasan pengetahuan (knowledge) yang ditindaklanjuti dengan wawasan praktek, melalui kegiatan latihan dengan menghasilkan portofolio (skill). Sedangkan kegiatan pendampingan adalah upaya dilakukan Perguruan tinggi untuk memastikan, mitra binaannya mampu mengaplikasikan ilmu pengetahuan dan teknologi kemasan pada produk mereka.

Workshop untuk produsen dan retailer dilakukan secara terpisah. Hal ini dilakukan karena masing-masing mempunyai fokus dan kebutuhan berbeda satu sama lain. Workshop dilakukan di lokasi mitra program. Pemilihan lokasi tersebut dengan pertimbangan untuk memudahkan pelaksanaan. Sistem ini dapat dikatakan sebagai sistem jemput bola. Tim pengusul menyadari sepenuhnya bahwa mitra program adalah seorang wirausaha yang sibuk dan cukup sulit untuk menghadirkan mereka dalam satu forum diskusi di kampus. Metode yang akan digunakan dalam workshop ini adalah:

a. Metode ceramah untuk memberikan wawasan mengenai material kemasan, dasar-dasar desain visual kemasan, komunikasi visual pada kemasan dan estetika kemasan.

b. Metode praktek dengan pendekatan group partisipatory. Peserta diarahkan untuk melakukan praktek didampingi 1 orang instruktur (tim dosen) dan dibantu oleh mahasiswa. Metode ini digunakan, dengan harapan peserta workshop dapat memperoleh hasil maksimal.

\section{Pendampingan}

Kegiatan Pendampingan dilakukan setelah kegiatan workshop selesai dilakukan. Tim peneliti memantau aktivitas mitra program. Setelah workshop, peserta diberi kesempatan selama 1-2 minggu untuk melakukan perencanaan terkait dengan kemasan produknya. Kemudian, ada tahap awal tim pengusul program akan kembali mengunjungi 
mitra untuk menyusun langkah-langkah desain program sampai dengan eksekusi pembuatan kemasan program.

Dalam pelaksanaanya, kegiatan pendampingan ini berfungsi juga sebagai kegiatan pemantauan (monitoring) pelaksanaan program. Monitoring dilakukan selama 1-2 bulan, kegiatan monitoring dilakukan dengan tujuan untuk memastikan transfer ipteks dapat dipahami dan diaplikasikan oleh mitra program. Dalam monitoring juga dilakukan invenarisasi permasalahan, sehingga memungkinkan untuk dilakukan improvement dalam proses transfer ipteks. Dalam kegiatan monitoring ini baik tim pelaksana IbM dari UNTIRTA maupun para anggota UMKM melakukan perbaikan berkelanjutan (continual improvement) untuk sehingga dicapai hasil yang maksimal. Kegiatan Ilmu Pengetahuan dan Teknologi bagi Masyarakat mengenai peningkatan daya saing produk usaha mikro melalui desain kemasan produk, dilaksanakan selama 8 (delapan) bulan.

\section{HASIL DAN PEMBAHASAN}

\section{Kontribusi Mitra}

Pelaksanaan IbM dilaksanakan dengan melibatkan peran aktif mitra. Oleh karena itu dalam pelasanaannya diperlukan kontribusi mitra sehingga program ini berlangsung dengan baik dan lancar. Untuk alat dan bahan worshop maupun produksi kemasan produk, disediakan oleh tim pelaksana IbM. Demikian juga untuk keperluan opersional sepenuhnya disediakan oleh tim Pelaksana IbM. Sedangkan beberapa bentuk kontribusi mitra dalam kegiatan IbM peningkatan daya saing produk usaha mikro melalui desain kemasan produk kue subuh, berupa :

1. menyediakan ruang pertemuan,

2. melakukan koordinasi dalam pelaksanaan workshop,

3. menyediakan produk kue subuh yang akan dibuatkan kemasannya,

4. memfasilitasi dan berperan aktif dalam kegiatan pendampingan.

\section{Peran Serta Mitra Dalam Kegiatan}

Satu hal yang menggembirakan dalam kegiatan IbM ini adalah antusiasme mitra program. Mereka mengangap bahwa materi pelatihan penting dan merupakan hal baru. Mereka sangat tertarik dengan pengetahuan mengenai kemasan dan fungsinya dalam 
melindungi produk. Mereka mengakui bahwa seringkali produk mereka rusak karena tidak dikemas dengan baik. Materi yang dinilai sangat bermanfaat adalah pengetahuan akan jenis kemasan dan material kemasan. Mereka baru menyadari bahwa ada beberapa materi kemasan yang mereka gunakan selama ini berbahaya bagi konsumen dan lingkungan.

Pada saat mitra program melakukan "praktikum", mereka antusias praktek membuat kemasan untuk produknya sendiri. Mereka antusias dalam membuat desain kemasan. Secara manual mereka membuat sketsa bentuk, kemudian memberikan warna. Pengetahuan dasar mengenai reka bentuk merupakan susuatu hal yang baru buat mereka, terlebih pengetahuan mengenai dasar-dasar warna dan aspek psikologis dari warna. Kesulitan muncul ketika mereka mulai membuat sketsa dengan menggunakan wacom, alat menggambar digital. Pengalaman baru karena merupakan suatu hal yang sangat asing. Tetapi dengan adanya workshop dan pendampingan, kesulitan-kesulitan dapat diatasi.

\section{Keberhasilan Program IbM}

Keberhasilan program $\mathrm{I}_{\mathrm{b}} \mathrm{M}$ Kelompok Usaha Produsen dan Retailer Makanan "Kue Subuh" sebagai suatu kegiatan pengabdian pada masyarakat ini dapat dikatakan berhasil karena telah sesuai dengan tujuan awal dilaksnakannya program ini. Setelah kegiatan $\mathrm{I}_{\mathrm{b}} \mathrm{M}$ Kelompok Usaha Produsen dan Retailer Makanan "Kue Subuh" pada mitra program yang dalam hal ini ada para pengusaha producen dan retailer kueh subuh yang bergabung dalam koperasi fórum UMKM “Makmur:" Banten dikasanakan diperoleh hasil sebagai berikut:

1. Bertambahnya pengetahuan para pengusaha mikro akan fungsi kemasan terhadap produk (isi), fungsi komunikasi pemasaran dan citra produk.

2. Bertambahnya pengetahuan para pengusaha mikro terhadap material kemasan produk, jenis dan bentuk, karakteristik serta pengetahuan akan estetika kemasan.

3. Tumbuhnya kesadaran akan pentingnya kemasan produk dalam membentuk citra produk yang pada kahirnya dapat menumbuhkan dan meningkatkan minat konsumen untuk membeli produk.

4. Tumbuhnya kemampuan para pengusaha mikro untuk merancang dan membuat kemasan produk 
5. Kemampuan produsen usaha mikro untuk mengaplikasikan pengetahuan dan keterampilan dalam merancang kemasan produk mereka.

\section{Keberhasilan Kegiatan di Mitra}

Keberhasilan kegiatan $\mathrm{I}_{\mathrm{b}} \mathrm{M}$ Kelompok Usaha Produsen dan Retailer Makanan "Kue Subuh" di mitra dapat dilihat dari beberapa indikator sebagai berikut :

1. Sambutan yang sangat positip baik dari pengurus dan maupun anggota koperasi fórum UMKM “Mandiri” Banten.

2. Keterlibatan dalam kegiatan pelatihan baik yang dilaksanakan di sekretariat koperasi fórum UMKM "Mandiri” Banten di jalan Yumaga Serang, maupun pelatihan yang dilaksanakan di kampus untirta.

3. Kesediaan untuk mencoba dan berlatih serta upaya yang dilakukan peserta untuk menciptakan desain dan membuat kemasan baru yang sesuai dengan kaidah-kaidah komunikasi pemasaran, branding dan desain komunikasi visual.

4. Dalam kegiatan pendampingan dengan mengunjungi beberapa rumah produksi industria kue subuh, mereka antusias dengan rencana desain kemasan yang baru untuk produk-produk mereka.

5. Adanya beberapa usulan untuk membentuk watu wadah semacam inkubator bisnis bagi UMKM yang dikelola oleh kampus UNTIRTA, dengan bersinergi dengan berbagai pihak terkait terutama dinas perindustrian provinsi Banten dan balai latihan kerja kota Serang.

Beberapa point di atas dapat dijadikan indikator bahwa kegiatan ini telah berhasil dengan baik karena kegiatan pelatihan dan pendampingan pada akhirnya telah membawa perubahan baik dalam aspek kognisi, afeksi maupun perilaku mitra yang berkelanjutan.

\section{DAFTAR PUSTAKA}

Aaker David \& Biel: 1993. Brand Equity \& Advertising: Advertising's Role in Building Strong Brands. USA.

Kotler, Philip. 2002. Manajemen Pemasaran Edisi Milemium, PT. Prenhallindo, Jakarta.

Peter \& Olson, 2000. Consumer Behavior perilaku konsumen dan strategi komunikasi pemasaran. Erlangga Jakarta 
Rangkuti, Freddy. 2007. Riset Pemasaran. - Cet. 1. - PT. Gramedia Pustaka Utama. Jakarta

Shimp, Terence A. University of South Carolina. 2003. Promotion Management \& Marketing Communication. The Dryden Press.

Sutisna. 2001. Perilaku Konsumen dan Komunikasi Pemasaran, Remaja Rosdakarya,

Yadin, Daniel L. 2009. Creating Effective Marketing Communications - Menciptakan Komunikasi Pemasaran Yang Efektif-. PT. Gramedia Pustaka Utama - Jakarta. 